\title{
Microbiology of the transition from acute to chronic maxillary sinusitis
}

\author{
I. BROOK, EDITH H. FRAZIER and P. A. FOOTE
}

Departments of Pediatrics, Georgetown University and Department of Otolaryngology, Alachua General and North Florida Regional Hospitals, Gainesville, FL, USA

\begin{abstract}
Repeated aspirations of sinus secretions by endoscopy was performed in five patients over a period of 34-50 days and, ultimately, surgical drainage was done in three who presented with acute maxillary sinusitis that did not respond to antimicrobial therapy and became chronic. The aspirates were cultured for aerobic and anaerobic bacteria. Most of the bacteria isolated from the first culture were aerobic or facultative bacteria: Streptococcus pneumoniae (three isolates), Haemophilus influenzae non-type-b (two) and Moraxella catarrhalis (one). Three of these cultures yielded bacteria that were resistant to the antimicrobial agents prescribed for treatment. Failure to respond to therapy was associated with the emergence of resistant aerobic and anaerobic bacteria in subsequent aspirates. These organisms included Fusobacterium nucleatum, pigmented Prevotella and Porphyromonas spp. and Peptostreptococcus spp. Eradication of the infection was achieved in all instances following the administration of antimicrobial agents effective against these bacteria, and in three instances by surgical drainage. This study illustrates the microbial dynamics of maxillary sinusitis that did not respond to antimicrobial therapy.
\end{abstract}

\section{Introduction}

Unresolving acute sinusitis that fails to respond to antimicrobial therapy can lead to chronic infection, with potentially serious local and systemic complications [1]. The management of this infection is often empiric, with the choice of antimicrobial agents not based upon the microbiology of sinus aspirates. The increasing incidence of resistance in many organisms isolated from acute and chronic sinus infections makes the management of these infections more complex.

The microbiology of acute sinusitis is well established; the major pathogens are aerobic and facultative bacteria - Streptococcus pneumoniae, Haemophilus influenzae and Moraxella catarrhalis [2]. Similarly, the bacterial aetiology of chronic sinusitis has been studied extensively $[1,3-5]$ and the predominant isolates are anaerobic bacteria. These include pigmented Prevotella and Porphyromonas, Fusobacterium and Peptostreptococcus species. However, no previous study has investigated the transitional stages and

Received 9 Jan. 1996; revised version accepted 14 March 1996.

Corresponding author: Professor I. Brook (present address: PO Box 70412, Chevy Chase, MD 20813-0412, USA). dynamics of the changes from acute to chronic infection.

Over a period of 34-50 days this study investigated the aerobic and anaerobic microbiology of five patients who presented with acute maxillary sinusitis that did not respond to antimicrobial therapy. Repeated samples of the sinus secretions, through sinus endoscopy, revealed the emergence of new microbial pathogens and the response of the patients to antimicrobial therapy.

\section{Patients and methods}

The five patients presented in this report were seen by the authors in the outpatient clinic for acute maxillary sinusitis. Patients' complaints included facial pain, frontal headache, purulent nasal discharge, fever or malaise. Inflammation of the maxillary sinuses was diagnosed after reviewing the clinical and radiological findings. Occipitomental (Waters' view), lateral, oblique and verticomental views were obtained. Sinusitis was defined radiographically as complete sinus opacity, an air-fluid level or mucous membrane thickening of at least $6 \mathrm{~mm}$ in the maxillary sinus. For the Waters' view, mucosal thickening of the maxillary sinuses was 
measured as the shortest distance from the air-mucosal interface to the most lateral part of the maxillary sinus wall. In each instance, the antimicrobial therapy indicated was started after culture had been obtained.

Specimens were obtained through maxillary sinus endoscopy under local anaesthesia, through the inferior meatus, or during surgery, employing strict asepsis to avoid contamination. Endoscopic collection of sinus secretions was done with calcium alginate tipped micro-swabs. Aspirates collected during surgery were transported to the laboratory in a corked syringe. The collected material was transported immediately to the microbiology laboratory where the swabs were placed in $1 \mathrm{ml}$ of pre-reduced saline and shaken vigorously for $2 \mathrm{~min}$, serially diluted, and inoculated into media supportive for aerobic and anaerobic organisms for quantitative and qualitative studies. The time between specimen collection and inoculation never exceeded $30 \mathrm{~min}$. For aerobic organisms the specimens were inoculated on to sheep blood, chocolate and MacConkey's agar plates, incubated at $37^{\circ} \mathrm{C}$ in air (MacConkey's agar) or in air with $\mathrm{CO}_{2}$ $5 \%$ (blood and chocolate agar), and examined after 24 and $48 \mathrm{~h}$. For anaerobes, the material was plated on to pre-reduced vitamin $\mathrm{K}_{1}$-enriched Brucella blood agar, a blood agar plate containing kanamycin sulphate and vancomycin hydrochloride, a blood agar plate containing colistin and nalidixic acid, and inoculated into enriched thioglycolate broth [6]. The plates were incubated in anaerobic jars and examined after 48 , 96 and $120 \mathrm{~h}$. The thioglycolate broth was incubated for 14 days. Aerobic and anaerobic bacteria were identified by previously described techniques $[6,7]$. Only bacteria found in numbers $>10^{4} / \mathrm{ml}$ were considered to be pathogens and included in the final report.

Antimicrobial susceptibility testing was done only for aerobic and facultative isolates by the method of Kirby and Bauer [7]. All S. pneumoniae isolates were found to be susceptible to penicillin after screening for penicillin resistance with an oxacillin disk. $\beta$-Lactamase activity was determined for all isolates with the chromogenic cephalosporin analogue 87/312 [8].

\section{Results}

Seven of the eight bacterial species isolated from the patients' first aspirates were aerobic or facultative bacteria (Table 1). These were $S$. pneumoniae (three isolates), $H$. influenzae non-type-b (two) and $M$. catarrhalis (one). Two organisms were isolated from three of the five patients. Three of the first cultures yielded organisms resistant to the antimicrobial agents given (nos. 1, 3 and 5). Some or all of the organisms isolated in the first culture persisted in the second one done 6-13 days later in three cases (nos 1, 3 and 5), and new species in addition to the old one were isolated in two instances (nos. 1 and 5); an entire change in the sinus flora was noted in two instances (nos. 2 and 4).

Only one anaerobic species (no. 5) was isolated in the first culture. However, anaerobic species were isolated from four patients (three were Peptostreptococcus spp.) in the second culture. The third culture (done 12-20 days later) revealed the presence of 12 anaerobic isolates in all five aspirates, and the disappearance of aerobic bacteria in two cases (nos. 4 and 5). These anaerobic bacteria were Peptostreptococcus spp. (four isolates), F. nucleatum (three) Prevotella spp. (three), and P. asaccharolytica (two).

$\beta$-Lactamase-producing bacteria (BLPB) were isolated from all of the patients (Table 1). BLPB were present in the first specimen in case 1, and emerged in the other cases in subsequent specimens. These organisms persisted through the fourth culture (done 18-38 days later) in those patients who received therapy not effective against them (cases 1, 2 and 4), but disappeared in those properly treated (cases 3 and 5) with antimicrobial agents active against these organisms (amoxycillin plus clavulanate or clindamycin). The fourth culture was obtained through drainage (inferior mental antrostomy) in three patients (nos. 1, 2 and 4).

\section{Discussion}

This study illustrates the dynamics of the isolation of micro-organisms from patients with acute maxillary sinusitis that did not respond to empiric antimicrobial therapy and became a chronic infection. The organisms isolated during the acute stage of the infections ( $S$. pneumoniae, $H$. influenzae and $M$. catarrhalis), are known causes of acute sinusitis [2]. Organisms resistant to the antimicrobial agents given were present in three of the five patients. These were $H$. influenzae and $M$. catarrhalis that were resistant to amoxycillin (case 1), $H$. influenzae that was resistant to erythromycin (case 3 ) and $S$. pneumoniae that was resistant to minocycline (case 5). These resistant organisms persisted in the infected sinus cavity, and newer pathogens were also isolated: Peptostreptococcus sp. (case 1), and F. nucleatum (case 5). New organisms were also isolated in the second culture, even in patients who received appropriate therapy, suggesting that factors other than antimicrobial resistance can enable organisms to survive in the inflamed sinus cavity.

Factors that may allow organisms to survive antimicrobial therapy within the inflamed sinuses are inadequate penetration of antimicrobial agents into the sinus cavity, a high protein concentration (that can bind antimicrobial agents), a high content of antimicrobial-inactivating enzymes (i.e., $\beta$-lactamase), decreased multiplication rate of organisms in the 
Table 1. Microbiology and antimicrobial therapy of five patients with maxillary sinusitis

\begin{tabular}{|c|c|c|c|c|c|c|c|c|c|c|c|}
\hline \multirow[b]{2}{*}{$\begin{array}{l}\text { Patient } \\
\text { no. }\end{array}$} & \multirow[b]{2}{*}{$\begin{array}{c}\text { Age } \\
\text { (years)/sex }\end{array}$} & \multicolumn{2}{|c|}{ First culture } & \multicolumn{2}{|c|}{ Second culture } & \multicolumn{2}{|c|}{ Third culture } & \multicolumn{2}{|c|}{ Fourth culture } & \multicolumn{2}{|c|}{ Fifth culture } \\
\hline & & $\begin{array}{l}\text { Bacteria isolated } \\
\text { (day 0) } \mathrm{cfu} / \mathrm{ml}\end{array}$ & Therapy (days) & $\begin{array}{l}\text { Bacteria isolated } \\
\text { (day) } \mathrm{cfu} / \mathrm{ml}\end{array}$ & Therapy (days) & $\begin{array}{l}\text { Bacteria isolated } \\
\text { (day) } \mathrm{cfu} / \mathrm{ml}\end{array}$ & Therapy (days) & $\begin{array}{l}\text { Bacteria isolated } \\
\text { (day) } \mathrm{cfu} / \mathrm{ml}\end{array}$ & Therapy (days) & $\begin{array}{l}\text { Bacteria isolated } \\
\text { (day) }\end{array}$ & Therapy (days) \\
\hline 1 & $23 / \mathrm{F}$ & $\begin{array}{l}\text { H. influenzae }(\mathrm{BL}+) \\
4 \times 10^{6} \\
\begin{array}{c}\text { M. catarrhalis }(\mathrm{BL}+) \\
6 \times 10^{6}\end{array}\end{array}$ & $\begin{array}{r}\text { Amoxycillin } \\
\text { (12) }\end{array}$ & $\begin{array}{c}(13) \\
\text { H. influenzae }(\mathrm{BL}+) \\
5 \times 10^{6} \\
\text { M. catarrhalis }(\mathrm{BL}+) \\
4 \times 10^{5} \\
\text { Peptostreptococcus spp. } \\
7 \times 10^{6}\end{array}$ & $\begin{array}{r}\text { Amoxycillin } \\
\text { (7) }\end{array}$ & $\begin{array}{c}(20) \\
\text { H. influenzae }(\mathrm{BL}+) \\
2 \times 10^{4} \\
\text { F. nucleatum }(\mathrm{BL}+) \\
3 \times 10^{6} \\
\text { Peptostreptococcus spp. } \\
3 \times 10^{7}\end{array}$ & $\begin{array}{r}\text { Amoxycillin } \\
\text { (7) }\end{array}$ & $\begin{array}{c}(28)^{*} \\
\text { H. influenzae }(\mathrm{BL}+) \\
5 \times 10^{5} \\
\text { F. nucleatum }(\mathrm{BL}+) \\
6 \times 10^{5}\end{array}$ & $\begin{array}{l}\text { Surgical } \\
\text { drainage } \\
\text { Amoxicillin- } \\
\text { clavulanate } \\
\text { (21) }\end{array}$ & $\begin{array}{c}(50) \\
\text { No growth }\end{array}$ & None \\
\hline 2 & $28 / \mathrm{F}$ & $\begin{array}{r}\text { S. pneumoniae } \\
3 \times 10^{7}\end{array}$ & $\begin{array}{r}\text { Amoxycillin } \\
\text { (7) }\end{array}$ & $\begin{array}{c}(8) \\
\text { Staph. aureus }(\mathrm{BL}+) \\
1 \times 10^{6} \\
\text { Pep. magnus } \\
8 \times 10^{7}\end{array}$ & $\begin{array}{c}\text { Ciprofloxacin } \\
\text { (6) }\end{array}$ & $\begin{array}{c}(14) \\
\text { Staph. aureus }(\mathrm{BL}+) \\
7 \times 10^{6} \\
\text { P. asaccharolytica } \\
6 \times 10^{7} \\
\text { F. nucleatum } \\
3 \times 10^{6} \\
\text { Pep. magnus } \\
9 \times 10^{6}\end{array}$ & $\begin{array}{c}\text { Ciprofloxacin } \\
\text { (10) }\end{array}$ & $\begin{array}{c}(24)^{*} \\
\text { Staph. aureus }(\mathrm{BL}+) \\
7 \times 10^{5} \\
\text { P. asaccharolytica } \\
5 \times 10^{5} \\
\text { F. nucleatum } \\
4 \times 10^{6}\end{array}$ & $\begin{array}{l}\begin{array}{l}\text { Surgical } \\
\text { drainage }\end{array} \\
\text { Clindamycin } \\
\text { (21) }\end{array}$ & $\begin{array}{c}(45) \\
\text { No growth }\end{array}$ & None \\
\hline 3 & $38 / \mathrm{M}$ & $\begin{array}{l}\text { H. influenzae } \\
\qquad 1 \times 10^{6}\end{array}$ & $\begin{array}{l}\text { Erythromycin } \\
\qquad(6)\end{array}$ & $\begin{array}{r}(6) \\
\text { H. influenzae } \\
6 \times 10^{7}\end{array}$ & $\begin{array}{c}\text { Erythromycin } \\
\text { (7) }\end{array}$ & 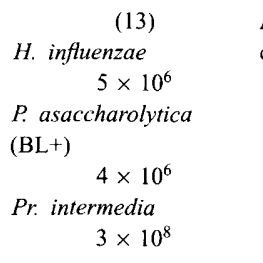 & $\begin{array}{l}\text { Amoxycillin- } \\
\text { clavulanate } \\
\qquad(10)\end{array}$ & $\begin{array}{l}\text { (23) } \\
\text { No growth }\end{array}$ & $\begin{array}{l}\text { Amoxycillin- } \\
\text { clavulanate } \\
\text { (11) }\end{array}$ & $\begin{array}{c}\text { (34) } \\
\text { No growth }\end{array}$ & None \\
\hline 4 & $32 / \mathrm{m}$ & $\begin{array}{l}\text { S. pneumoniae } \\
\qquad 4 \times 10^{7} \\
\alpha \text {-haemolytic } \\
\text { streptococci }\end{array}$ & $\begin{array}{l}\text { Cefaclor } \\
\text { (7) }\end{array}$ & $\begin{array}{c} \\
\text { Pr. melaninogenica } \\
\text { (BL+) } \\
\\
2 \times 10^{7}\end{array}$ & $\begin{array}{l}\text { Cefaclor } \\
\qquad(5)\end{array}$ & $\begin{array}{lc} & (12) \\
\text { Pr. melaninogenica } & \\
(\mathrm{BL}+) & \\
& 4 \times 10^{6}\end{array}$ & $\begin{array}{l}\text { Cefaclor } \\
\text { (5) }\end{array}$ & $\begin{array}{lc} & (18)^{*} \\
\text { Pr. melaninogenica } \\
(\mathrm{BL}+) \\
\\
& 2 \times 10^{7}\end{array}$ & $\begin{array}{l}\text { Surgical } \\
\text { drainage }\end{array}$ & $\begin{array}{c}\text { (34) } \\
\text { No growth }\end{array}$ & None \\
\hline & & $3 \times 10^{6}$ & & $\begin{array}{l}\text { Peptostreptococcus spp. } \\
\qquad 4 \times 10^{6}\end{array}$ & & $\begin{array}{l}\text { Pr. oralis }(+) \\
\quad 7 \times 10^{7} \\
\text { Peptostreptococcus } \mathrm{sp} \\
\quad 5 \times 10^{6}\end{array}$ & & $\begin{array}{c}\text { Pr. oralis }(+) \\
2 \times 10^{7} \\
\text { F. nucleatum }(\mathrm{BL}+) \\
1 \times 10^{7}\end{array}$ & $\begin{array}{l}\text { Amoxycillin- } \\
\text { clavulanate } \\
\text { (15) }\end{array}$ & & \\
\hline 5 & $26 / \mathrm{m}$ & $\begin{array}{l}\text { S. pneumoniae } \\
\quad 8 \times 10^{7} \\
\text { Peptostreptococcus spp. } \\
\quad 7 \times 10^{6}\end{array}$ & $\begin{array}{r}\text { Minocycline } \\
(6)\end{array}$ & $\begin{array}{c}(7) \\
\text { S. pneumoniae } \\
3 \times 10^{6} \\
\text { F. nucleatum } \\
1 \times 10^{7}\end{array}$ & $\begin{array}{r}\text { Minocycline } \\
\text { (7) }\end{array}$ & $\begin{array}{c}(14) \\
\text { F. nucleatum }(\mathrm{BL}+) \\
8 \times 10^{6} \\
\text { Peptostreptococcus sp. } \\
\quad 6 \times 10^{7}\end{array}$ & $\begin{array}{r}\text { Clindamycin } \\
(24)\end{array}$ & $\begin{array}{l}\text { (38) } \\
\text { No growth }\end{array}$ & None & $\ldots$ & . \\
\hline
\end{tabular}


sinus cavity that can interfere with the activity of bacteriostatic agents, and increased acidity within the sinus cavity that reduces the efficacy of some antimicrobial agents (i.e., aminoglycosides and quinolones) [9].

This study illustrates for the first time the transition that occurs in the microbiology of maxillary sinusitis as the infection gradually progresses from acute to chronic. As chronicity develops, the aerobic and facultative species are gradually replaced by strictly anaerobic bacteria. These changes may be due to the selective pressure of antimicrobial agents that enable resistant organisms to survive. Moreover, the effects of chronic infection may lead to the development of conditions appropriate for the growth of anaerobic bacteria. These changed conditions include the reduction in oxygen tension and an increase in acidity within the sinus cavity. These are caused by the persistent oedema and swelling within the sinus cavity which reduces blood supply and, therefore, the consumption of oxygen by the aerobic component of the sinus cavity bacterial flora $[10,11]$. Other factors are the emergence over time or selection of anaerobic bacterial strains that possess essential virulence factors such as a capsule [12].

The emergence of new pathogens in all instances, mostly strict anaerobes, generated a polymicrobial infection. This type of infection is synergic [13], and may be more difficult to eradicate with narrow spectrum antimicrobial agents. In such mixed infection, mutual enhancement of bacterial growth [14], and 'protection' of penicillin-susceptible isolates by $\beta$ lactamase produced by penicillin-resistant bacteria [15], may contribute to the chronicity of the infection, and the difficulty in its eradication.

This study illustrates that failure to respond to $\beta$ lactam antibiotics, tetracyclines, quinolones or macrolides can be associated with the presence of resistant organisms. Recent studies illustrated the increased isolation rate of BLPB in numerous upper respiratory tract infections [16]. The number of these BLPB was shown to increase following administration of $\beta$ lactam antimicrobial therapy [17]. Although judicious selection of antimicrobial agents is essential for the management of sinusitis [18], surgical intervention for correction of pathology and evacuation of pus is frequently required, especially in patients who fail to improve with antimicrobial therapy.

The isolation of aerobic and anaerobic BLPB from this type of infection requires the administration of appropriate antimicrobial agents for adequate treat- ment. Second-generation cephalosporins and the combination of amoxycillin and clavulanate, can provide coverage against the major causes of acute sinusitis. Activity against anaerobic BLPB, common in chronic infection, can be achieved by clindamycin, chloramphenicol, metronidazole (plus a penicillin or a macrolide), the combination of a penicillin (e.g., amoxycillin) and a $\beta$-lactamase inhibitor (e.g., clavulanate) or imipenem.

We acknowledge the efforts of the clinical and laboratory staffs, and the secretarial assistance of Sarah Blaisdell and Joanie Pietrafitta.

\section{References}

1. Frederick J, Braude AI. Anaerobic infection of the paranasal sinuses. $N$ Engl J Med 1974; 290: 135-137.

2. Jousimies-Somer HR, Savolainen S, Ylikoski JS. Bacteriological findings of acute maxillary sinusitis in young adults. J Clin Microbiol 1988; 26: 1919-1925.

3. Evans FO, Sydnor JB, Moore WEC et al. Sinusitis of the maxillary antrum. $N$ Engl $J$ Med 1975; 293: 735-739.

4. Carenfelt C, Lundberg C, Nord CE, Wretlind B. Bacteriology of maxillary sinusitis in relation to quality of the retained secretion. Acta Otolaryngol 1978; 86: 298-302.

5. Brook I. Bacteriological features of chronic sinusitis in children. JAMA 1981; 246: 967-969.

6. Summanen P, Baron EJ, Citron DM, Strong CA, Wexler HM, Finegold SM. Wadsworth anaerobic bacteriology manual, '5th edn. Belmont, CA, Star Publishing Co. 1995.

7. Murray PR, Baron EJ, Pfaller MA, Trenover PC, Yolken RH. Manual of clinical microbiology, 5th edn. Washington DC American Society for Microbiology, 1993.

8. O'Callaghan $\mathrm{CH}$, Morris A, Kirby SM, Shingler AH. Novel method for detection of beta-lactamases by using a chromogenic cephalosporin substrate. Antimicrob Agents Chemother 1972; 1: 283-288.

9. Carenfelt C, Eneroth C-M, Lundberg C, Wretland B. Evaluation of the antibiotic effect of treatment of maxillary sinusitis Scand J Infect Dis 1975; 7: 259-264.

10. Aust R, Drettner B. The oxygen exchange through the mucosa of the maxillary sinus. Rhinology $1974 ; 12$ : 11-23.

11. Carenfelt $\mathrm{C}$, Lundberg $\mathrm{C}$. Purulent and non-purulent maxillary sinus secretions with respect to $\mathrm{pO}_{2}, \mathrm{PCO}_{2}$ and pH. Acta Otolaryngol 1977; 84: 138-144.

12. Brook I, Myhal LA, Dorsey CH. Encapsulation and pilus information of Bacteroides spp. in normal flora abscesses and blood. J Infect 1992; 24: 252-257.

13. Altemeier WA. The pathogenicity of the bacteria of appendicitis peritonitis. An experimental study. Surgery 1942; 11: 374-384.

14. Brook 1. Enhancement of growth of aerobic and facultative bacteria in mixed infections with Bacteroides species. Infect Immun 1985; 50: 929-931.

15. Brook I. The role of a beta-lactamase-producing bacteria in the persistence of streptococcal tonsillar infection. Rev Infect Dis 1984; 6: 601-607.

16. Brook I. Beta-lactamase-producing bacteria in head and neck infection. Laryngoscope 1988; 98: 428-431.

17. Brook I, Gober AE. Emergence of beta-lactamase-producing aerobic and anaerobic bacteria in the oropharynx of children following penicillin chemotherapy. Clin Pediatr 1984; 23: 338341.

18. Brook I, Thompson DH, Frazier EH. Microbiology and management of chronic maxillary sinusitis. Arch Otolaryngol Heart Neck Surg 1994; 120: 1317-1320. 